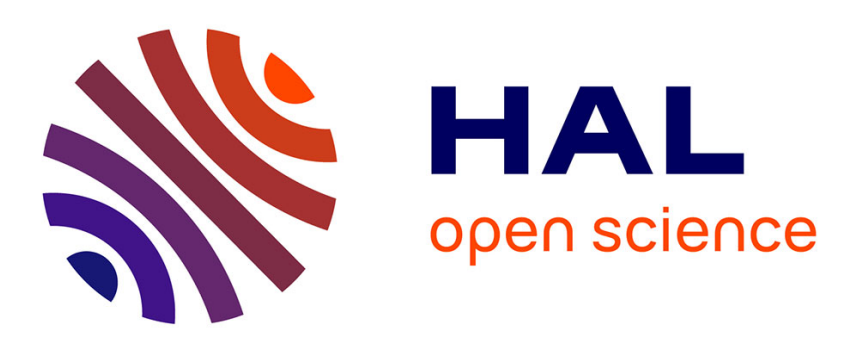

\title{
Eco-frontier and place-making: the unexpected transformation of a sustainable settlement project in the Amazon
}

Xavier Arnauld de Sartre, Vincent Berdoulay, Raquel da Sulva Lopes

\section{- To cite this version:}

Xavier Arnauld de Sartre, Vincent Berdoulay, Raquel da Sulva Lopes. Eco-frontier and place-making: the unexpected transformation of a sustainable settlement project in the Amazon. Geopolitics, 2012, 17 (3), pp.578-606. 10.1080/14650045.2011.631199 . halshs-00768269

\section{HAL Id: halshs-00768269 \\ https://shs.hal.science/halshs-00768269}

Submitted on 21 Dec 2012

HAL is a multi-disciplinary open access archive for the deposit and dissemination of scientific research documents, whether they are published or not. The documents may come from teaching and research institutions in France or abroad, or from public or private research centers.
L'archive ouverte pluridisciplinaire HAL, est destinée au dépôt et à la diffusion de documents scientifiques de niveau recherche, publiés ou non, émanant des établissements d'enseignement et de recherche français ou étrangers, des laboratoires publics ou privés. 


\title{
ECO-FRONTIER AND PLACE-MAKING: THE UNEXPECTED TRANSFORMATION OF A SUSTAINABLE SETTLEMENT PROJECT IN THE AMAZON
}

\author{
Xavier ARnAUld de SARTRE \\ Vincent BERDOULAY \\ Raquel DA SILVA LOPEZ
}

\begin{abstract}
Two models are competing for the appropriation of the lands which remain unused by modern societies, such as tropical forests. This paper focuses on the attempt to link an agricultural frontier, driven by economic objectives, with conservationist views. In the Amazon, family farmers are addressed by this kind of project since they are at the same time actors of the agricultural frontier and considered as potential actors of the preservation of the forest. This paper, based on the study of this kind of settlement in the Pará State, aims to understand the role that family farmers can play in meeting sustainability goals. This objective implies to understand the land relation of these populations through notions that don't presuppose the nature of these relations, such as the one used in the studied project, but that leave them to build themselves on terms close to those of place-making.
\end{abstract}

\section{INTRODUCTION}

Since the conflict between "developers, destroyers and defenders of the Amazon" was analysed at the end of the 80 s by S. Hecht and A. Cockburn', "the fate of the forest" is still greatly dependent on resolving the contradictions between diverging proposals for the Amazon. Over the past few years, colonisation of the Amazon in a globalisation context has taken a new turn, making intensive agro-industrial production its main objective ${ }^{\mathrm{ii}}$. At the same time, a way of legitimising conservation of the Amazon is developing not only through the protection of traditional populations and the fight against deforestation, but also through the protection of biodiversity and the upkeep of ecosystemic services ${ }^{\mathrm{iii}}$.

These different proposals for the same area can be seen as an opposition between a productivist frontier and an ecological one. A frontier can be considered as a change in the socio-spatial order; but while the productivist frontier gives colonisation economic objectives, "the eco-frontier aims at transforming and sustaining the uses of a territory according to environmental priorities and concerns" ${ }^{\text {"iv }}$. This phenomenon is particularly evident in the Amazon. Both frontier types has its own spatial core: the western Amazon for the eco-frontier, and the middle-western and north-eastern Amazon for the productivist frontier. As they progress in space, they may enter into conflict within the same territory ${ }^{\mathrm{v}}$. 
This is the case in various areas of the Amazon, where many conflicts over land tenure are occurring. The expansion of the frontier was historically achieved in Brazil through particularly ill-defined land tenure regimes, which made access to the land dependant on labour and social power relations ${ }^{\mathrm{vi}}$. These relations prevailed until the 80 s and even beyond, making the stabilisation of land access the starting point for development policies, sustainable or otherwise, in the Brazilian Amazon ${ }^{\text {vii }}$. In the productivist frontier, a new land tenure structure is being implemented through the recognition of individual property rights, with no size limitation. In the ecological frontier, non individual land tenure is emphasised, particularly through the designation of protected areas (national park, indigenous reserve, extractivist reserve, national forest, etc.).

In other words, each of these frontier types favours a different category of population: "traditional populations" (Amerindians and riverside inhabitants) are relied upon within the ecological frontier, whereas modern farmers are within the productivist frontier. However, there are populations, which are neither completely capitalist nor traditional, and which fit neither of these two categories. This is particularly the case of family farmers in the Brazilian Amazon, which are criticised for their weak economic efficiency by some, or for the too rapid turn over in their slash and burn practices by others. Nevertheless, since land reform policies have reached a greater importance in the Amazon ${ }^{\text {viii }}$, the role of this category of population is becoming a crucial issue. Family farmers are increasingly viewed as actual or potential key actors for the development of the ecological frontier, because their practices are supposed to be compatible with nature protection.

Thus, this point of view leads to the issue of conferring and devising a significant role for the inhabitants of the ecological frontier. The problem of land rights is linked to different conceptions of the role devoted to settling population in development projects. In this context, a particular type of colonisation, called PDS ("Projeto de desenvolvimento sustentavel", i.e., "Sustainable development project"), has been devised in order to accommodate these populations' demands to land access with the aim of protecting the environment. Nevertheless, sustainability projects based on "small-scale producers" are far from being successful ${ }^{\mathrm{ix}}$. No doubt, strong divergent interests and related power relations led in 2008 to the resignation of Marina Silva as minister of the Environment. As former colleague of Chico Mendes, she was highly symbolic of the chance given by the then president Luis Ignacio Lula da Silva to the development of positive links between sustainability and small-scale producers. It is significant that the press interpreted her resignation as a failure of this development model.

The main objective of this paper is to contribute to the understanding of the potential role that family farmers can play in reaching sustainability goals in a planned eco-frontier settlement. This potential cannot be achieved by simply adapting models already used for traditional populations and by transferring them to local family farmers. It also requires the understanding of the relationship of these populations to the land through notions that don't presuppose the nature of these relations. 
The central argument of our analyses is that we need a different way of approaching the local level in order to meet our objective. More precisely, we intend to show that the sustainability goal of a reciprocal reinforcement of environmental and social parameters can be achieved through a place-based approach in an eco-frontier. The geopolitical problematics of eco-frontiers is complex: It is social, economical, and environmental as well ${ }^{\mathrm{x}}$. While much of the recent geopolitical literature has thus focused upon the power relationships that promote eco-frontiers and conflicts within them, very little is known about the processes, which may lead to the emergence of a sustainable place. Learning more about them can help to overcome the "parochiality" of much recent geopolitical literature, whereby problematics from the "North" are too directly applied to the "South"xi. Cannot the understanding of place-making processes be part of the answer for better integrating geopolitical research with other types of geographical knowledge ${ }^{\mathrm{xii}}$ ? In other words, it is important to examine how placemaking is interacting with the problematics of the eco-frontier.

What happened with the emblematic Sustainable Development Project of Nova Esperança, set up thanks to the initiative of Sister Dorothy in Anapu, State of Pará, in the Brazilian Amazon, provides a useful case in point for clarifying these issues. As an attempt by its promoters to base sustainable development on the empowerment of a pre-defined local community, it turned out to be a relative failure. However, an examination of the transformations of the initial project reveals an emerging potential for place-based sustainability practices.

Therefore, this paper will begin by discussing the issue of how to approach the role of non-traditional family farmers in sustainability projects at a local level in light of the existing debates about place. Based on field work, the following sections will focus on the outcome of Sister Dorothy's project and on what can be learnt from it: The eco-frontier/development issue as a major geopolitical context for the project; the assessment of the project's results in relationship to its initial goals; the transformation of the project, not only for explaining to what extent the initial project failed but also for identifying what is emerging from local practices as far as the sustainability goal is concerned in eco-frontiers.

\section{Place-making as a way out of the local trap}

There is a large international acceptance of the idea that sustainable development is best achieved at, and through, a local level, as illustrated by the success of Local Agenda 21. This view has recently received some critical attention and it is occasionally questioned. From this perspective, a special issue of Geoforum in 2005 explored local abilities with regards to sustainable development. The guest editors justified their programme as follows: "The importance of the 'local' in development, sustainable or otherwise, may be justifiable given these political economic times, but to date, precious little detailed empirical research supports it", and they asked the fundamental question: "Do local places have the capacity to promote sustainable development?"xiii. Like other authors in this special issue and researchers in other 
fields, they focused their interest on political-economic factors which could promote the implementation of sustainable development. Their sense of the importance of locality comes from acknowledging that sustainability policies have been built on an international, global level, and on universal norms, which are often at odds with local practices $^{\text {xiv }}$. Not surprisingly, then, the meaning of sustainability and the ways in which it can be implemented may greatly differ according to context.

According to Sharp ${ }^{\mathrm{xv}}$, greater attention should be given to the implementation of sustainability goals and policies, in order to better understand how these are modified and how interpretations of them compete with one another and have to be negotiated. Similarly, Houghton argues that there is a crucial "need to consider the ways in which local contexts set the terms for interpretations of sustainability as these conceptualisations can direct actions for sustainability and may interrelate to assist or hinder the implementation of local level sustainability plans"xvi . She goes further by trying to give theoretical content to the idea of context by drawing attention to the notion of place, to the role of power relations and to environmental worldviews. However, what is considered as "local" in these discussions tends to refer to an area, or better to a territory, as defined by relations of power; consequently, the term "local" does not bring with it all the human, spatial and environmental complexity that it could convey. In other words, according to this literature, the local level would possess some contextual qualities, which make it influence the way sustainability practices are understood, discussed and implemented. This tendency to endow the local level with a positive impact on the search for sustainability should be questioned.

Above all, the so-called local population does not necessarily have an interest in adopting sustainable practices. As it depends on the local environment for its food, health and way of life, this population is assumed to have an interest in preserving the environment from destruction. But this is not always the case: in many situations, the local people may have an interest in profoundly transforming the environment, and even in destroying its natural potential. In the Amazonian context, Brown and Purcell $^{\text {xvii }}$ showed that, in many cases, local populations have an interest in forest clearing - and that this is what they do. As an example from elsewhere, in a South African case study, King ${ }^{\text {xiii }}$ (2007) showed that some groups have negative perceptions of community conservation. In fact, it can be argued that two types of tropisms restrict the understanding of the significance of the local level.

The first tropism comes from the uncritical community orientation of much of the literature. Steven Brint argues that, thanks to his critical study of the sociological use of the community concept, "there is a considerable confusion about the meaning and consequences of communal relations"xix. Context of interaction among members, proximity, choice, belief, activity, and motivation are all among the various parameters of community related phenomena. No single meaning or significance can be attributed to the term community ${ }^{\mathrm{xx}}$. This is certainly the case when we consider sustainable development projects. While the use of the terms "local community" may create an impression that the population is homogeneous, studies show that this is far from true. Acknowledging the diversity of rural populations, their past, objectives or resources ${ }^{\mathrm{xxi}}$, should be a basis for determining any capacity for sustainable development. In the 
Amazonian context, X. Arnauld de Sartre showed the different histories and objectives of family farmers who live in the frontier areas, and he concluded that this diversity implies different ways of practicing agriculture, different impacts on the environment and different objectives relative to sustainable development: While sustainability can be a necessity for some family farmers to maintain their production methods, and while for many it is a way of sustaining their families, for others it is a constraint that prevents them from accumulating land and cattle ${ }^{x x i i}$. This is why local population as community should not be taken for granted in a sustainable development project and why its diversity should be acknowledged.

The other tropism comes from the policy-oriented frameworks used by most analysts. Locality is basically viewed through the eyes of sustainability projects. What interests researchers is not so much local dynamics but local level policies. As a consequence of this approach, all the attributes of a locality that are pinpointed by the analysts are those which directly relate to the success or the failure of policies. In so doing, the numerous relationships among attributes which structure locality escape the attention of analysts, leaving them unaware of key or potentially key linkages. Therefore, there are interesting articles on the issue of the implementation of sustainability policies by political or institutional actors at a local level ${ }^{\text {xxiii }}$; however, this literature reduces locality to specific policy related aspects. Of course, there are calls for a better understanding of local complexity, but how far is this idea pursued?

Here, scale is an important issue: Is the local level the most significant scale for describing and assessing the main aspects of sustainability policies? The critique of the local scale can in fact be extended to scale itself. It can be argued that scale is not necessarily a container of an autonomous system, polarising what would be inside and outside. The argument of scale has led many researchers to consider that there is nothing inherent about scale, but rather that it is "socially constructed"xxiv; consequently, "the key question is not whether territory is socially constructed but how it is constructed"xxv . Nevertheless, this type of question eschews the issue of locality as the optimum scale for promoting sustainability. Given the examples where this was not the case, the idea of pursuing policies along this optimum local scale can be denounced as a "scalar trap" or, more specifically, a "local trap", as Brown and Purcell ${ }^{\text {xxvi }}$ wrote by adapting the idea of the "territorial trap" criticised by Agnew ${ }^{\mathrm{xxvii}}$ in the study of international relations. This local trap characterises much of what is done in terms of sustainability policies, and it goes as far as encouraging researchers facing implementation failures to look for specific, exceptional reasons rather than questioning the local scale for which the project was formatted.

Even if scale should not be taken for granted, the very fact that a policy or a development project unfolds at a certain spatial level makes scale a reality. The "politics of scale" create a "process of scaling through which multiple spatial units are established, differentiated, hierarchised and, under certain conditions, rejigged, reorganised and recalibrated in relation to one another"xxviii. This process does not necessarily lead to a territorial structuring of space: Many socio-spatial organisations can co-exist and the local level territory is just one possibility among many others. Through this perspective, the existence of networks could be seen as opposed to the 
local level, but it can also be viewed as complementary with the local scale. In environmental policy in particular, networks are very efficient because they can transcend specific scales ${ }^{\text {xxix }}$. But, how can we still account for some significance of the local level without falling back into the local trap?

We argue here that a way out of this all pervasive local trap can be provided by giving closer attention to the concept of place. Clearly, "place" is mentioned by various authors as an important parameter for studying the context of the implementation of sustainable policies, but these calls for place tend to equate it with a local area and consequently fall into the local trap. As already mentioned, they consider the local level only through its attributes related to the policy at hand. They posit what scale is significant and they define the limits of a territory, which is thought of as pertinent. Even when there exists a concern for the geographic contribution of the concept, its examination and use remain limited, so that "places can be understood as distinct localities with unique economic, social and physical characteristics" ${ }^{\mathrm{xxx}}$. As a concept, place has more significance.

There is a huge amount of literature on the concept of place as it develops previous discussions on the regional concept in geographic studies, and, over several decades, it has cut across most paradigmatic changes in social science epistemology $^{\mathrm{xxxi}}$. In spite of often strong divergences in this literature, several arguments on relatively common themes are relevant to our goal and their convergence allows for our use of the concept. First of all, the concept of place is viewed as a social construction, and it draws attention to localised interactions of numerous, and quite different phenomena, which can be natural, social, economic, political, cultural, etc. The aim is to see how various strands of processes interact across spatial scales and create specific conditions of life and a context for individual or collective action. Conflicts and levels of authority are not left out of this search for interaction, as it is evidenced in the way the concept of place helps to elucidate geographies of resistance $^{\mathrm{xxxii}}$ (Pile and Keith, 1997). Through this perspective, the concept of place and its focus on emergent properties has proved to be useful for explaining - and connecting - aspects of Amazonian political ecology, such as violence, deforestation, and agrarian reform ${ }^{\text {xxiii }}$.

In these types of issues, it is clear that the emphasis is on social construction, on spaces defined by power relations, but it is equally clear that more experiential aspects of place are also important. This is because place serves as the means through which agents conceive, perceive, and construct their spaces of action ${ }^{\text {xxxiv }}$. This interest for the actual experience of individuals is another broad area of focus in the literature written on place. For some authors, it is at the root of what place is about and what place is becoming $^{\mathrm{xxx}}$. For others, it has inspired research on the role of affect, and, more extensively, on the whole issue of the spatial dimension of subjectivity ${ }^{\text {xxxvi }}$.

Thus, place can be viewed as related to subjectivity and objectivity, materiality and experience, and human and physical aspects of reality. For this reason, what best characterises it is its "betweenness" "xxxvii . Through this perspective, place takes form by means of the interplay of multiple narratives. These narratives are significant for the experience of, and action by, the individuals who contribute to their emergence and 
transformation. The idea is not to focus on territorial limits or on a specific set of socio-political variables; but rather special attention should be given to process and strategy, to narration, to milieu from the point of view of its inherent complexity and contingency, and to individual creativity, which it allows or spurs ${ }^{\text {xxxviii }}$. Furthermore, this perspective makes it possible to give due attention to the reflexive ability of the individuals who are assessing their situation and making decisions ${ }^{\mathrm{xxxix}}$.

Through the use of the concept of place, our aim is to consider the capacity for reflexivity and self-organisation that local populations can evidence. A priori, we cannot prevent even the most isolated populations, like the trans-Amazonian settlers, from being minimally aware of their situation in the world due to their mobility, their access to mainstream media, the presence of members of other organisations in their settlement (such as development workers, missionaries, politicians, researchers, etc.). In becoming aware of other scales, local people may also become aware of their own local situation, helping them to act locally.

Furthermore, this perspective in our use of the concept of place extends to a specific set of agents; those who are involved in planning or local development. Many of them aim to create or to develop awareness among the individuals they are working with about their place and role in the world. Interestingly enough, in Brazil, environmental education, partially inspired from Paulo Freire's educative approach ${ }^{\mathrm{xl}}$, has been used to serve this purpose ${ }^{x l i}$. In other words, our use of the concept of place allows for an approach to planning whereby projects and policies are grounded in the reflexivity of both the planners and the concerned population ${ }^{\text {xlii }}$. This is why, in our fieldwork, we have been very attentive to the emergence of reflexive practices among all actors involved.

\section{The context: Eco-frontier versus development}

It has become quite difficult to qualify Brazilian policy for geopolitics in the Amazon, mostly because of the changing ways of exercising state sovereignty in an age of globalisation and devolution, especially in connection with environmental issues. The policies being applied in the Amazon may be considered as schizophrenic, since some of them are designed to accelerate colonisation of the Amazon while others are clearly conservationist ${ }^{\text {xliii }}$. This contradiction between two kinds of policy may be strongly related to the notion of the ecological frontier, whereby the concern for environmental issues recasts all terms of the debate between them. Here we recall several observations.

Firstly, a characteristic aspect of policies in the Amazon region is that a law can be passed but never applied because funds, means of enforcement or simply information are lacking. These policies are known as "policies on paper".

Secondly, the two kinds of policies are not designed to be applied in the same area $^{\text {xliv }}$. For instance, the federal Project for a Sustainable Amazon (Plano Amazônia sustentável, PAS) is based on a zoning plan for the whole of the Amazon basin, with three main types of area; each of them has its own objectives and agenda, whether for conservation or for development (see Fig. 1). Only in a few cases (the "focal point 
areas") do the two kinds of logic (colonisation versus conservation) compete with each other.

Thirdly, in the Brazilian Amazon there are multiple scales and actors. Globalisation, devolution and conflicts about environmental issues have profoundly transformed the territoriality of the Brazilian State and, consequently, the State itself ${ }^{\mathrm{xlv}}$. Traditionally, the Brazilian State, particularly in the Amazon basin, is characterised by "a nested hierarchy of spatial scales"xlvi, each scale with its own prerogatives. Alongside the Federal State, federated states and municipal authorities have the power to act in favour of or against colonisation (building vicinal roads, authorising land occupation, etc.). The democratisation of Brazil has complicated these statehood conflicts since "civil society" has increased its power and has to be consulted before every important decision is taken. Furthermore, the emergence of international concern over the Amazon has complicated relationships between actors. Since NGOs can influence or act at each scalar level and with any kind of actor, they make it extremely complex to understand how any specific decision is made ${ }^{\text {xlvii }}$. Nowadays, none of these scales can be considered as homogenous.

The imbrications of scales and the contradictions within each scale must be acknowledged before approaching any environmental project in the Amazon, especially as far as the ecological frontier is concerned. For instance, different objectives for the Amazon compete with one another within the Federal State itself, among ministries, with some in favour of development and others of conservation, and with potential changes connected to the results of elections or to policy choices. There are also different views within the social movement, within NGOs, etc. These different aims for the Amazon exist within and among scales, so that an analysis of specific alliances is necessary in order to understand the kind of action that is being observed and could be developed in favour of sustainable policies ${ }^{\text {xlviii }}$.

In ecological frontiers of the Brazilian Amazon, a social-oriented conception of nature structures the debate on conservation. It is called "socio-environmental" (socioambiental in Portuguese): modernity (and capitalism in general) is considered to have deformed them and to have made the poor dependent on the over-use of natural resources $^{\text {xlix }}$. Historically, it was in strong interaction with social reform movements led by the Catholic Church, which was partially influenced by the "theology of liberation". The aim of socio-environmentalists is to find ways to make local populations aware of their condition and to return to, or acquire, a balanced relationship with nature ${ }^{\text {li }}$. A growing number of NGOs and actors in public institutions take inspiration from this socio-environmentalism, which emphasises action with local populations ${ }^{\text {lii }}$. In so doing, these NGO and public actors are striving for the building of specific territories, which make more secure access to the land; they also hope for establishing sustainable relationships between inhabitants and their environment. Also this type of action may is not aimed at place making, it may emerge from the becoming of the project. This was clearly exemplified in the Nova Esperança project.

\section{Assessing the Nova Esperança project}


In our chosen example, socio-environmentalism had some partial repercussions among stakeholders of the project, which were supposed to prevent destructive frontier expansion. They were members of the "social movement", such as unions and related associations backed by the Catholic Church, which was very well established in the region. They made an alliance through the active implication of a nun from the Pastoral Land Commission (Comissão Pastoral da Terra, or CPT) for setting up the "Sustainable Development Project of New Hope" - Projeto de Desenvolvimento Sustentável (PDS) Nova Esperança - that should help in stopping the destructive expansion of settlements in the forest.

The location of Nova Esperança in the Amazonian context is shown in figure 1: It is located within a border zone between an increasingly settled "population belt" and a still relatively preserved "Central Amazon". This situation gives it a crucial role in defining what major land uses and sustainability practices will resist the nonsustainable strategies that could spread from the "population belt". It is a sector where development and conservation policies are applied at the same time. On the one hand, a mega-project for a dam on the Xingu River (the Belo Monte Dam) has been planned near Altamira since the late 1970s and should be built within the next ten years, strengthening development plans for the Amazon ${ }^{\text {liii }}$. At the same time, land tenure for many family farmers is being recognised in the land-reform policy of Brazil's President, Luis Ignacio Lula da Silva, and this is accelerating the agricultural frontier's expansion process. On the other hand, the Federal State has adopted an intense policy for creating protected areas. A mosaic of protected areas has been created in the nearby Terra do Meio area.

Nova Esperança occupies a small part of the municipio of Anapu, whose population is fast growing: 9,400 inhabitants according to the census in $2000 ; 19,410$ inhabitants as estimated by the Brazilian Institute of Geography and Statistics at the end of 2008. Anapu extends on both sides of the Trans-Amazonian highway, in the area of the National Altamira Integration Plan, one of the farming frontiers supported by the Federal State during the 1970s with the aim to integrate the Amazon to the national territory. Unlike the areas to the west of Altamira, Anapu was mainly dedicated to cattle ranching on large tracts of land. The family farmers who settled in Anapu were, to begin with, mostly employees of large-scale landowners, but they have gradually become landowners themselves. Today, the municipio area is shared between family farmers and fazendeiros (large-scale landowners who reserve their land for cattle ranching). Family farmers' access to private property has caused conflicts in some cases, a "place-specific history engendered a landscape of violence"liv, and the farmers' unions developed conflicting relationships with the large landowners. This is why the Pastoral Land Commission, an offshoot of the Catholic Church, has been particularly active in the region since the mid 1980s, when the struggle for land rights was intensified.

Due to the dam project, new possibilities for land acquisition, and the frontier's own dynamics, many people arrived in the region of Anapu at the beginning of this century, looking either for employment in dam construction or for access to land. 
Claims for vast tracts of land and also for small plots (by poorer people) were (and still are) competing over the remaining accessible areas of Anapu.

It is in order to face this conflictual situation that the Anapu "social movement" (as it is called there) decided to create a PDS. It was formally proposed in 1999, under the leadership of Sister Dorothy, a nun from the Pastoral Land Commission. This North American-born nun, who was granted Brazilian citizenship during the 1990s, conceptualised the PDS and promoted it until she was murdered in 2005 by those in opposition to the project. She was supported by the Catholic Church, by the social movement in the Altamira region such as the FVPP (Fondation Viver Produzir Preservar, i.e., Live, Produce and Preserve, whose members are family farmers' unions and various associations) and by different federal agencies who were interested in her project.

The argument developed by Sister Dorothy about the rationale of the project is still widely maintained among the actors concerned: We were repeatedly told that the municipio of Anapu was being "surrounded" by large-scale landowners and pastures, and that the only way to prevent this from happening was to create a socio-ecological frontier settlement (fronteira socio-ambiental). As usual, settlement projects (projetos de assentamento - PA) - the main way for family farmers to gain access to land tenure - were considered to be a cause of destructive frontier expansion. The idea was to create alternative land-use and land-tenure systems in order to bring change to the frontier.

The need for controlling the negative aspects of the expansion of the frontier explains why the PDS was conceived as a territory with specific laws: as such, the PDS clearly was the result of regional geopolitics. The solution that was found to give an institutional and yet experimental status to this alternative settlement project was to turn it into a Sustainable Development Project (PDS). Land tenure in the PDS is inspired by the "extractive reserves" set up for the seringueiros (rubber-tappers) in the State of Acre, and therefore it is not individual but collective: each farmer has the use of a plot of land, but cannot sell it. The collective land-tenure system was above all a way of avoiding selling land to the fazendeiros. This is because, in many frontier areas, some family farmers sell their land to fazendeiros soon after having acquired it, a process which would have made the alternative settlement project pointless. In some cases, fazendeiros can even push poor families to take on land until they sell it to them. As it was later explained to us by Bruno Kempler, responsible for the National Institute for Colonization and Agrarian Reform (INCRA) local office in Altamira when the PDS was set up, the "goal of collective land-tenure was to remove lands included in the land reform from the market". At the same time, in order to avoid the expansion of pastures that frequently follows forest clearance, the family farmers were supposed to take part in training courses on sustainable activities, especially perennial cropping, forest management and joinery in order to make use of the timber locally. In particular, a sustainable forest management community project was planned: It aimed at promoting a sustainable use of forest timber, whose benefits could be shared among the community members. 
Nova Esperança extends over a total of 15,223 hectares. It is subdivided into 317 plots of 50 hectares which are distributed along three parallel roads, connected perpendicularly by a fourth road (fig. 2). Given that all of the plots are not occupied, its population in 2008 was approximately 600 permanent residents.

However, the reality of the PDS today is quite different from the "PDS on paper", as the Chairman of the association of the PDS inhabitants calls it. Our study is based on two kinds of data. They are first drawn from the research that some of us have been doing in this region for more than 10 years, including many interviews with local actors, and since 1997 with Sister Dorothy in particular (up until a few months before she was murdered). More recently (2008), in connection with a research project $^{\mathrm{lv}}$, we carried out field studies to collect data systematically: we did semistructured interviews and systematic surveys with the head of every institution linked to the PDS (the local association of PDS inhabitants; the Pastoral Land Commission; the ASSEFA, i.e. the agricultural assessment service provider of the PDS; officials from the INCRA; the region's social movement), two key actors in the region and many farmers.

In 2007, using a questionnaire, we interviewed 64 families, who represented around one third of plot owners resident in the PDS, chosen through random sampling. The interviews were administered by the Brazilian member of the team, who lived for a few months in the area as part of the preparation of her $\mathrm{PhD}^{\text {lvi }}$. A long discussion with the members of the family always preceded the interview in order to establish a relationship of trust and confidence between the interviewer and them. This close relationship reduced biases which could have come from the fact that it was often men who spoke during the formal part of the interview. Although this is common thought in the settlement that the man should act as the spokesperson for the family, most of the time his wife stayed for the whole interview and answered many questions. One the one hand, the aim of the survey was to describe the main characteristics of the inhabitants of the PDS, to compare them to traditional, riverside inhabitants, and to other settlements already visited by the research team in the Amazon. On the other hand, the aim was also to know the reasons why the inhabitants decided to settle in the PDS and their opinion about its functioning. Table 1 summarizes some of the characteristics of these residents.

\begin{tabular}{|c|c|c|c|c|c|c|c|c|c|}
\hline \multicolumn{2}{|c|}{ Sex } & \multicolumn{2}{|c|}{ Age } & \multicolumn{2}{|c|}{$\begin{array}{c}\text { Number of } \\
\text { migrations during } \\
\text { life }\end{array}$} & \multicolumn{2}{|c|}{$\begin{array}{l}\text { Number of } \\
\text { children }\end{array}$} & \multicolumn{2}{|c|}{ State of birth } \\
\hline Male & 54 & $\begin{array}{l}26-33 \\
\text { years }\end{array}$ & 16 & $\begin{array}{l}2-3 \\
\text { migrations }\end{array}$ & 3 & $\begin{array}{l}1-3 \\
\text { children }\end{array}$ & 30 & Para/Tocantins & 22 \\
\hline \multirow[t]{3}{*}{ Female } & 10 & $34-40$ & 14 & $\begin{array}{l}4-5 \\
\text { migrations }\end{array}$ & 12 & $\begin{array}{l}4-6 \\
\text { children }\end{array}$ & 18 & Maranhão & 24 \\
\hline & & $41-46$ & 18 & $\begin{array}{l}6-8 \\
\text { migrations }\end{array}$ & 9 & $\begin{array}{l}7-9 \\
\text { children }\end{array}$ & 16 & Other nordeste & 18 \\
\hline & & $50-61$ & 14 & $\begin{array}{l}9-13 \\
\text { migrations }\end{array}$ & 5 & & & & \\
\hline
\end{tabular}

Table 1 - Main indicators of the studied population in the PDS 
This population is not different to other assentamentos populations of the agrarian reform $^{\text {lvii }}$. It is important to stress that most of the people we encountered were present at the beginning of the project (table 2). In our sample, only 2 of the farmers interviewed arrived after 2005, when the project had already been created. All of them were present when Sister Dorothy was still alive, and were aware of the special status of the PDS. Even if it is difficult to know the turn over of families in the PDS, our sample shows that it was, in 2007, marginal. At the same time, the people we interviewed maintained that they agreed with the PDS (table 2). Even though these data should be considered carefully since they were answers to closed questions which were asked by students from the university, we have structured the semi structured interviews on the farmers' opinion about the PDS. We interviewed 12 inhabitants of the PDS, and many actors concerned by the project: the priest of the Anapu parish (Padre Amaro, twice with an interval of one year), the members of the "technical contractor linked to the PDS", the bursar of the INCRA of Altamira when the PDS was created (Bruno), the head of the FVPP (Paulinha), and the chairman of the association of inhabitants of the PDS (Fabio).

\begin{tabular}{|cc|cc|}
\hline \multicolumn{2}{|c|}{ Time passed in the PDS } & \multicolumn{2}{|c|}{ Opinion of the PDS } \\
\hline 2 years & 2 & Positive & 36 \\
3-4 years & 50 & Indifferent & 16 \\
$5-6$ years & 10 & Negative & 12 \\
\cline { 3 - 3 } 7 years & 2 & & \\
\hline
\end{tabular}

Table 2 - The population and the PDS

\section{Transformations of the project}

Two points must be stressed when writing about the situation of the PDS today. Firstly, it is obvious for many actors that the PDS is not what it was supposed to be. It has reached a point where the members of the INCRA who were interviewed were not able to describe what Nova Esperança is today: "Today, it is not clear what the PDS has become with all these transformations. It is not a traditional PA, but it is not a PDS", admitted Fabio the Chairman of association of PDS inhabitants. Clearly, the "PDS on paper" has not been materialised.

Secondly, the discourses by the PDS founders (the members of the social movements that promoted the concept and project of the PDS) are not clear at all. At the start of the project, its promoters were able to clearly explain its philosophy and goal. But in 2008, these discourses were less structured, much more difficult to analyse - and in many cases to understand. It was difficult to obtain a clear narrative of the history of the project and of the main issues today. Of course, the promoters' narratives about the PDS evolved at the same time as the project itself: The narratives lost their structure when the project lost its initial geopolitical goals. The differences between what was initially planed and what occurred should not to be interpreted as a failure of the project; rather, it may well be reflection of the making of a place by the PDS 
inhabitants who wanted to have better control of the management of their land, environment and community.

\begin{tabular}{|c|c|c|c|c|}
\hline \multirow{3}{*}{$\begin{array}{l}\text { Legal } \\
\text { context }\end{array}$} & & "PDS on paper" & Traditional PA & PDS today \\
\hline & $\begin{array}{l}\text { Environmental } \\
\text { legislation }\end{array}$ & \multicolumn{3}{|c|}{$\begin{array}{l}20 \% \text { forest clearing outside legally protected areas } \\
\text { (margins of rivers, etc.) }\end{array}$} \\
\hline & $\begin{array}{l}\text { Legal status of } \\
\text { the land }\end{array}$ & \multicolumn{2}{|c|}{ Stabilised } & $\begin{array}{l}\text { Not stabilised in } \\
\text { the contested } \\
\text { areas }\end{array}$ \\
\hline \multirow[t]{3}{*}{$\begin{array}{l}\text { Land } \\
\text { tenure } \\
\text { system }\end{array}$} & $\begin{array}{l}\text { Land tenure } \\
\text { settlement }\end{array}$ & Collective & Individual & $\begin{array}{l}\text { Concession of } \\
\text { land use on } \\
20 \% \text { of the plot } \\
\text { of a farmer. The } \\
\text { remaining } 80 \% \\
\text { are dedicated to } \\
\text { forestry } \\
\text { management }\end{array}$ \\
\hline & $\begin{array}{l}\text { Plot } \\
\text { arrangement }\end{array}$ & $\begin{array}{l}\text { Disjunction for } \\
\text { each plot of the } \\
\text { productive part } \\
(20 \%) \text { and the } \\
\text { forested part } \\
(80 \%)\end{array}$ & \multicolumn{2}{|c|}{$\begin{array}{l}\text { The two parts of the plot are } \\
\text { contiguous }\end{array}$} \\
\hline & $\begin{array}{l}\text { Location of the } \\
\text { plots }\end{array}$ & $\begin{array}{l}\text { The productive } \\
\text { part of all plots } \\
\text { are located in the } \\
\text { area of the PDS } \\
\text { where there are } \\
\text { richer soils }\end{array}$ & & \\
\hline \multirow[t]{3}{*}{$\begin{array}{l}\text { Internal } \\
\text { rules }\end{array}$} & Collective work & $\begin{array}{l}\text { Every activity is } \\
\text { decided and } \\
\text { conducted } \\
\text { collectively }\end{array}$ & \multicolumn{2}{|c|}{$\begin{array}{l}\text { None, except for some community } \\
\text { assets (building of schools, road } \\
\text { management) }\end{array}$} \\
\hline & Cattle breading & $\begin{array}{l}\text { Limited to } 5 \\
\text { hectares of } \\
\text { pasture and } 7 \\
\text { animals }\end{array}$ & $\begin{array}{l}\text { No limitations } \\
\text { in accordance } \\
\text { with the rules } \\
\text { on } 20 \% \text { forest } \\
\text { clearing }\end{array}$ & $\begin{array}{l}\text { Limited to } 5 \\
\text { hectares of } \\
\text { pasture and } 7 \\
\text { animals }\end{array}$ \\
\hline & $\begin{array}{l}\text { Transformation } \\
\text { of products }\end{array}$ & Joinery & None & $\begin{array}{l}\text { Failure of } \\
\text { joinery } \\
\text { activities }\end{array}$ \\
\hline
\end{tabular}

Table 3 - Comparison of the functioning of the PDS on paper, a traditional PA, and the PDS today 
Table 3 compares what the present PDS, the "PDS on paper", and a traditional PA are according to the main indicators used to describe each one. It shows why the PDS can be considered neither a "PDS on paper", nor a PA. Many rules and actions planned by the promoters of the PDS and funded by external financial agencies came to nothing. Two main reasons should be mentioned: The legal status of the PDS, which had not been sorted out by the State; and the planned land tenure regime, which was in contradiction with the wishes of the members of the PDS. In other words, several planned internal and external rules were resisted, thwarted, or rejected by the inhabitants. However, it should be underlined that they created and followed new internal rules for the functioning of the PDS.

\section{Inheritance and state responsibility}

The first problem that emerged in this project is one of inheritance. Some of the chosen lands for the PDS are claimed by a large-scale landowner. The problem is the following: most Amazonian lands are reputed to be "free", i.e., with no landowner. In the region of the Altamira, the land up to one hundred kilometres on either side of the Trans-Amazonia highway was nationalised in the early 1970s. When the State transferred ownership of the land that it had under its jurisdiction, it was under condition that the land was to be used to create economic value: the State had the right to take land back if this was not achieved within five years of the transaction. This is a legal act called retomada de posse, the withdrawal of ownership. However, it has been used to a minimum; consequently, the status of land that has not been put to economic use is not clear, since it is the property of a landowner who is no longer the legitimate owner.

This was the case with part of the area where the PDS was established. The land had an owner, but its title was not yet valid because it was not productive. When its owner realised that the plots were being occupied by others, he protested, and he deforested vast areas in order to create pasture, so that he could claim to have not lost his right to the land. On the PDS side, the founders had a title deed certifying that the contested land was reserved for the PDS. As neither side was willing to give up their rights, the conflict between them grew resulting in the death of Sister Dorothy, who was murdered by two hired killers. Even if it is quite usual, in this region, to solve the land tenure conflicts with violence ${ }^{\text {lviii }}$, it must be stressed that the paid murder of a 72 years old North American-born nun proved that violence reached a hardly imaginable point.

The death of Sister Dorothy caused a great commotion, so that the project's institutionalisation suddenly accelerated: the PDS, which had not been authorised until Sister Dorothy was murdered, was officially created just after her death - but not in the contested areas. This situation caused difficulties for the whole project since the status of settlers in the contested area had not been legalised. At the same time, the PDS is located on the boundary of indigenous land: legally, no colonisation project can be 
established within 30 kilometres around indigenous land. This means that, according to the law, some of the settlers should not be there.

The consequences of this situation are important: as funding for agriculture and house building depends on the legal status of the settlers, family farmers in the contested part of the PDS have no access to any official financial help. Similarly, forest clearing, which farmers have to do in order to plant their crops, is subject to authorisation that cannot be given to the farmers because in some areas they are farming illegally. Neither should the forestry management project have been allowed, since it concerns the whole area of the PDS.

The "State" is responsible for this situation. Two main structural and organisational problems are at issue. Firstly, there is a conflict between scales. It is the federal scale which authorises the PDS in the land it has under its jurisdiction. But the protest against this jurisdiction was brought before the courts of the State of Pará, since it has jurisdiction over land tenure conflicts. The second problem is at the federal level, among the various agencies: There was no coordination between the indigenous people's agency (FUNAI) and the family farmers' agency (INCRA) before settlement was authorised.

This is the reason why many PDS officials are calling on the "State" to assume its own responsibilities. But this problem arising from state contradictions is not the only problem for the PDS.

\section{The land tenure issue and the choice of individual ownership}

The choices and decisions made on land ownership are the reason for the main differences between the PDS "on paper" and today's PDS. The initial idea was that land ownership should be collective, but not land use. Each farmer would be allocated 50 hectares, but this "plot" would have been divided into two separate pieces: $20 \%$ (10 hectares) for his own use and the remaining $80 \%$ (40 hectares) reserved for a collective forestry management project. However, this design turned out to be confusing. One the one hand, despite collective land tenure, the very fact that each farmer could use his own "plot" and live on it provided a satisfactory illusion of ownership. On the other hand, at the beginning of any classic colonisation movement, farmers do not own the land they are using and, after a period of time, they can claim ownership (provided that no one else does so). As this does not seem very different from the concession they received from the PDS, the difference remained quite unclear to them. Understandably, they pushed for receiving their own plot in one single tract rather than in two separate pieces. And this was what happened at the very beginning of the actual settlement process.

At the same time, cultivated land is not separate from forestry land. Whereas in the PDS "on paper" all cultivated tracts were supposed to be concentrated in the same section, giving birth to a village, while the remaining forested section would have been exploited collectively, the settlement process rests on single tract plots and a relatively dispersed population. The PDS promoters accepted this change in their initial project, fearing that the large section devoted to forestry with no visible owner would have 
been too much of a temptation for outside migrants to invade. Individual land use was thought to make this invasion difficult.

State officials and trade unions organisers, whom we interviewed about the development of the PDS, explained to us several times that this was the first wrong decision when implementing the project. It has indeed determined much of what followed: When a farmer is the owner of his land, it is difficult to impose upon him more than what the law specifies.

Nevertheless, in terms of sustainability, some goals have been achieved, especially with respect to forest preservation and cattle ranching prevention. This can be illustrated by comparing the PDS area to its surroundings, which are colonised according to usual practices. Figure 2 and table 4 shows the evolution of the percentage of pasture and forest in the area of the PDS compared to an area within a radius of 20 kilometres of it. The rate of deforestation is lower in the PDS than in the non PDS area: nearly $90 \%$ of the PDS area is still forest, and the area of pasture is quite small. The rate of deforestation in the non PDS area is nearly twice what can be observed in the PDS, while the rate of pasture creation in the non PDS area is 2.5 times greater than in the PDS (table 4). It can reasonably be argued that transportation facilities contribute to explaining this difference: However difficult to quantify, accessibility was greater for some parts of the surrounding areas than for the PDS, because roads were opened since 2001 in the former, whereas the latter is entirely accessible by cars only since 2006. But, the non PDS area also includes an indigenous reserve which has not been deforested at all, so that the deforestation rates of the non PDS area are underestimated. Furthermore, rather than rates of deforestation, it is the shape of deforested areas which makes the comparison more significant (figure 2). In the PDS, very small plots of deforested areas can be observed. They are quite different from the areas deforested both by the fazendeiros (which are very large, with geometrical limits) and by the traditional family farmers (deforestation all along the roads).

\begin{tabular}{|c|cc|cc|}
\cline { 2 - 5 } \multicolumn{1}{c|}{} & \multicolumn{2}{c|}{ PDS area } & \multicolumn{2}{c|}{ Non PDS area } \\
& Forest & Pasture & Forest & Pasture \\
\hline 2001 & $97.70 \%$ & $0 \%$ & $91 \%$ & $2 \%$ \\
2007 & $89.60 \%$ & $3.85 \%$ & $76 \%$ & $12.50 \%$ \\
\hline
\end{tabular}

Table 4 - Evolution of percentages of forest and pasture in the PDS and its surroundings within a $20 \mathrm{~km}$ radius.

The difference in the amount and shape of deforested areas, which can be observed in the PDS, stems not only from a probable influence of deficient transportation facilities, but also from the internal rules which have been followed by the PDS. This points to a significant difference, which emerged between the PDS as it evolved and any classic PA, and which had much to do with the self-organisation of Nova Esperança (as it will be shown in the following section). Even if the PDS project 
was born in rather exceptional circumstances, the settlers have decided to modify or reject many of the planned rules and actions in order to go their own way.

\section{Community, place, and reflexive practices}

Even if the Nova Esperança PDS is subject to the same rules as standard PAs, it has a self-organisation that ultimately differentiates it from them. Even though the internal rules set up within the PDS have nothing to do with the collective functioning originally planned, they contribute to some sense of collective identity for its inhabitants. However, this sense should not be over-emphasised. Indeed, the ideals of the PDS promoters, especially those belonging to the "social movement" or to the Pastoral Land Commission, converged around communitarian values. Now, a community, with all its communal sharing of work, goods and decisions, is far from what can be observed in Nova Esperança. If the term community may be used to refer to this settlement, it should be done only with a very loose meaning and without the communal functioning that it could imply. At any rate, place-related issues and processes showed to be significant for understanding what is actually emerging in Nova Esperança.

Initially, the PDS inhabitants were supposed to plant, harvest and exploit the forest collectively. Map 2 allows us to see the place where the fields were originally planned to be (on the best land), and where the village for all the farmers should have been constructed. It was even planned that agriculture would have been practiced collectively. In the end, not only was no collective farming practiced, but each farmer had his own determined plot, making the initial project null and void. No work took place outside the family unit.

This is the case even for joinery, which was also supposed to have been practiced collectively, but never was. The farmers who were trained in joinery had a workshop and were provided with tools by the development project. They were supposed to share the income from the joinery production with the community, and at the very least pay for their professional expenses. What happened is that they did not share this income; consequently, when their collective tools began to wear out, they could not be renewed, as no money was available. In the end, the workshop had to stop its activity, and when we did our last field study (2008), a year after cessation of activity, it still hadn't been re-established.

The only truly collective asset that was bought was a pick-up truck to travel between the PDS and the city of Anapu, in order to sell the produced goods. This pickup was bought with the money earned from renting a pasture to a large-scale landowner (a fazendeiro). The irony is that this pasture had been created illegally within the PDS boundaries by the fazendeiro, the very same person who is supposed to have hired Sister Dorothy's murderers! This money was thus obtained from an illegal pasture that should have never been rented out...

Fabio, the chairman of the association of PDS inhabitants explained the failure of the strong collective dimension that was planned by the PDS venture: 
Well, you know, I think that this collective venture was not possible as the people are very different from one another. They come from very different regions, everybody has a different profile.

The PDS was a destination for migrants from very different regions of Brazil, and the settled families have very different cultural and social backgrounds. The PDS promoters ignored this reality that was in contradistinction with their expectations for a spontaneous collective functioning. The same misrepresentation of the diverse backgrounds of family farmers occurred with respect to the expected collective land tenure. Many settlers were not landowners in the regions that they came from. For many of them, the possibility of owning their land made them endure the hardships of life in the frontier area. As a result of this, these farmers accepted collective property with the hope that they could some day achieve private ownership of their plot. In fact, not one of the farmers we met said that he or she was really convinced by collective ownership. At the moment, farmers apply all decisions in the least collective way possible, being quite clear about the quasi private management of their plot.

When a farmer told us about his arrival in the PDS, he explained that he had not wanted, under any circumstance, to live where the village was to be constructed but that he wanted to live on his plot, cultivating it. Weighing up the four years spent in the PDS, his wife said:

It was worth it, because I can tell you one thing: my husband's dream was to farm his own land, to grow what he wanted to grow, to breed his cattle, because it was his dream to milk his own cows. Living on other people's land, this isn't possible, because we are only authorised to cultivate a piece of land, to crop it and we even have to pay for cropping, and that's all, we are as we were before, we cannot even cultivate one permanent or semi permanent plant such as manioc or mamão. Now we are able to grow what we want to grow, and that is a victory; so our land is called Boa Vitoria (good victory), because for us it was a victory.

In other words, the initial project was based on an erroneous perception of who the inhabitants would be. In the minds of the project promoters, these inhabitants would have behaved as traditional peoples of the Amazon are expected to behave, governed by community rules. Fabio, the chairman of the association of PDS inhabitants, is conscious of this situation, and explains it clearly:

Here, in fact, the people of the ASSEFA have been to visit Santarem (the Flauna Tapajos, a conservation unit for traditional populations). It works there, because the community has been there for over 300 years, the same families live there, which makes the reality very different from here, where there are people that come 
from Pará, Tocantins and Nordeste. All with different mentalities. It is much more difficult to make collective wellbeing work here, with these types of people, than it is in Santarém.

However, even though they do not enjoy the benefits of modernity, family farmers are part of national Brazilian society, and their aspirations are in tune with the main characteristics of this society, where private property is much more valued than collective property $^{\text {lix }}$. The PDS promoters' expectations for a collective functioning of the settlement could not be materialised because they postulated as evidence that its population would form a community in a strong meaning of the term. In this respect, one could speak of the PDS as a failure, for the simple reason that communal feeling and behaviour does not exist. But one should not stop at this observation, because emerging phenomena can be seen. These become visible when we look less at social relations alone and more at the various interactions that make up a place. It can be argued that this was what the PDS promoters failed to anticipate when they postulated communal organisation rather than planned place dynamics at the root of their project.

Even if the inhabitants do not form the community that they were expected to form, this does not mean that local feeling doesn't exist and that the local scale is not appropriate for such projects. Many observations can be made, which tend to show that the policy of scale, daily life, shared problems, and the learning process among inhabitants is producing something different not only from what was expected but also from a simple project failure. What is emerging takes form from the reflexive practices that are invented for living in, and with, place.

We have noticed that the discourses of PDS promoters are difficult to analyse, as they are not particularly coherent. On the contrary, the discourses and narratives of the PDS inhabitants that we interviewed were much more structured. An illustration of this is given by the already quoted citation from the chairman of the association of the PDS inhabitants. He has clear ideas about the nature of the PDS and how it functions, about the mistakes made over the years and about the limits and opportunities of the PDS; he was also quite able to draw up a typology of the inhabitants of the PDS, to assess the action of the State or to analyse the strategies of various regional socioeconomic actors.

Many inhabitants of the PDS demonstrated the same capacity for analysing their own situation, a capacity that was not shown by PDS promoters.

One inhabitant, whose opinion on the PDS was indifferent, said:

The visible difference between the PA and the PDS is that the PDS has more control especially with regards to deforestation. Here, the organisation attempts to make sure that there are no more than 3 hectares per year of deforestation. We already know how much we can cut down on our plot or what we must use in an alternative way, so we don't run the risk of overstepping these restrictions without knowing. The organisation's management is very insistent with regards to controlling people, the APP [Area of permanent 
protection], and cattle rearing. But it is very clear that we cannot live of livestock farming on this land, so the organisation tries to teach us to farm other crops, like cocoa.

Another inhabitant, with a negative opinion, said:

Here it's not like in the other PAs, where everyone cuts down all the trees in order to have pastures. The problem is that we can't get steady technical support.

All of the inhabitants stress that the PDS is like a traditional PA but that it functions under more restrictive environmental legislation. Paradoxically, the internal rules of the PDS that are similar to those of a PA may contribute to the creation of a sense of community. When a farmer is a candidate for land in the PDS, he or she has to be interviewed by the officials of the association of inhabitants. The candidate is tested and the rules of the PDS are explained. Every farmer who joins the PDS knows these rules and accepts them, however reluctantly, because they are viewed as a restriction on their individual freedom.

Other internal rules of the PDS are the limitation on cattle ranching, the obligation of residence and the prohibition of selling one's plot when leaving. The two latter rules were decided by the PDS promoters in order to avoid the concentration of land in the fazendeiro's hands. They imply that when a farmer leaves the PDS, the only thing he can sell is the work he has done on his plot - not the plot itself. In general, the farmer is not supposed to find a buyer for his land himself; the association takes the next farmer on the waiting list of applicants for land in the PDS. The first rule - the limitation of cattle ranching - was decided in order to limit deforestation and to provide an incentive for alternative land uses such as perennial crops or the use of forest products. The problem is that this rule implies that adequate training should have been provided for the farmers who may have limited knowledge about these alternative land uses.

Even if these rules are sometimes accepted reluctantly, they have helped to build some sense of local community. As they have the same problems, the farmers can organise themselves to claim their rights and find solutions. The capacity for local, reflexive self-organisation within the PDS is noticeably greater than elsewhere. For example, the association of inhabitants is appointed for solving many problems; both majors problems (like the funding of house construction projects or the choice of a technical support association), and also day to day problems (family difficulties, conflicts between neighbours, problems with schools, etc). According to:

We hold meetings, sometimes once a week in every group of inhabitants, and we talk about particular situations to do with the project. Every month there is a managerial meeting within the organisation, and we get together to make decisions. We cannot make people act differently, but the people that are here know that they are 
not in a traditional PA, they know that they are in Sister Dorothy's PA, therefore they know that they must listen to the organisation.

They are aware that they live in a highly symbolic place - a legacy of Sister Dorothy's advocacy - and that they have been promised benefits that never happened; all of this contributes to their active self-organisation in dealing with other actors. They keep up to date with information and influential networks provided by the institutions and various organisations that promoted the PDS. Nova Esperança is not an isolated bounded territory; it is a place, which, in spite of its very poor socio-economic level, stays reflexively connected to the outside world. The contact with the outside world is all the more frequent as the PDS is connected daily with the city of Anapu by the pickup truck. But it is mainly the contact with external organisations that is important: The PDS benefits from numerous development projects: technical support projects, literacy tuition projects, forest management projects, participation at the Anapu farming markets; likewise, the PDS sends children to the Rural Family Houses in the region. Even if these projects aren't PDS-specific, the PDS is more often than not included as an area in a development programme on the Transamazonian scale. This guarantees regular external visits to the PDS.

The same reflexive dimension can be observed when the inhabitants demonstrate their capacity to make collective decisions about the inner organisation of the PDS. One example that illustrates this was when money was earned through the community forestry management project. The question of the distribution of this money was raised during a participatory meeting of the PDS inhabitants. The day before the meeting, rural technical advisers who were members of the ASSEFA (a technical service linked to Sister Dorothy) visited each house to argue in favour of a distribution system where $80 \%$ of the money would be for collective use and $20 \%$ for personal use. This solution was adopted during the pre-scheduled meeting. But a few days later, the PDS inhabitants decided to organise another meeting, and it was voted that the money was to be distributed the other way round. Our interviews clearly showed that they were against the initial distribution and that they were aware of having been influenced by the pre-meeting encounters. This decision reveals, at the very least, that the community is capable of reflexive practices; in this case, organising itself in order to obtain what it really wants, despite external pressure.

Many meetings are organised in order to make decisions concerning the functioning of the PDS. We have already mentioned that money was earned through renting a pasture established by the fazendeiro, who accepted this temporary compromise even though he kept fighting against the appropriation by the PDS of what he considered his property. A meeting was organised to decide what should be done with the money from renting the pasture, and it was decided to buy a pick-up truck. When it was delivered, another meeting was organised to decide who the drivers would be and how much they would be paid. These matters, and many others, were decided upon collectively, even though it would have been possible for the decisions to be made by a restricted group of farmers. 
Obviously, this self-organisation is far from the communal life hoped for by Sister Dorothy and by other PDS promoters at the start of the project, but it shows that some sense of community is emerging from the inhabitants' local adaptation of the project policy. Of course, it is not a Gemeinschaft, in the sense attributed to it by Ferdinand Tönnies; rather, in the words of S. Brint" communities of place" where many status hierarchies are possible but where the use of instruments of community building may lead to a greater sense of common destiny. Throughout the brief history of the PDS, we have witnessed this growing sense of community. While it was almost impossible to perceive it at the beginning of the project, it became increasingly evident throughout the years, especially when we did our last field study. This growing sense of community is clearly fostered by local policy, in particular by the adopted internal rules, by the realisation of a common condition for all the inhabitants of the PDS, and by a local process of learning how to interact with one's milieu - with others and with the environment.

In other words, it is not so much this emerging but weak sense of community that should be emphasised as a political achievement. Rather, it is the constant process of transformation of both people and the environment. This process involves individual subjects whose diversity converges towards the construction of a place, which is highly significant to them all. This place cannot be characterised solely as being socially constructed. It can equally (if not preferably) be said that the emerging loose local community is geographically constructed. Community is more the result than the cause of the emergence of place. The experienced interaction among different incoming settlers is at the root of the place that is emerging and evolving in Nova Esperança. The challenges, which each individual has been facing while settling in the PDS, can be understood through place-making.

\section{Conclusion}

Compared to what was originally planned, the Sustainable Development Project of Nova Esperança comes out as a failure in many respects. Basically, its strongly collective organisation and the accompanying innovative ecological management that was hoped for did not emerge. At first glance, the planned social dimension of sustainability and the creation of an ecological frontier in the Amazon forest were not achieved. At best, it seems to have led to another, hardly viable settlement of forested lands by family farmers. This should not be surprising when we consider that the Amazon is far from being ecologically managed: Many contradictions of the policies that are being implemented in the region are reflected in today's Nova Esperança. Nevertheless, what became of the PDS is a relative success in terms of local sustainability.

In the "PDS on paper", the inhabitants were supposed to be at the core of the project. Even when this was the case, we have seen that the reality of their origins and of their hopes had nothing to do with the expectations of the PDS promoters. The latter ignored the inhabitants' diverse social, cultural and regional origins, assuming that they would spontaneously form a well-knit community with strong communal values. 
None of this occurred. However, what seems different from what happens in other classic settlement projects is that the individual inhabitant of the PDS is well aware of the importance of his or her involvement in the conduct of the project, with the necessity of collectively protecting one's rights.

Contrary to what the promoters of the PDS thought, the sense of a strong local community, especially in a settlement frontier, is not ontologically given; it cannot be achieved either by simply training farmers (or subcategories among them) or by private ownership limitations. What the PDS promoters failed to see, and what occurred in Nova Esperança, is that some form of local community can take place. It is constructed through the multiple life histories of the inhabitants of the same area, through the struggles and the failures of the project, through the various individual interactions with the milieu, and through the accounts that are produced. With their capacity for reflexive self-organisation, the inhabitants of Nova Esperança have built up a sense of place, which is quite different from what has happened in other projects.

Although this was not expected at the start of the project, what occurred and is still occurring in Nova Esperança is a process of place construction. Presently, it can be said that the future of Nova Esperança as a sustainable community depends on the development of this construction. Furthermore, it can be argued that place-making should be a more explicit goal of sustainability policies in eco-frontiers. Rather than considering locality as a simple context that gives bias or help to sustainability policies, and rather than focusing on social parameters only, one should pay more attention to place-making as the creative locus of sustainable actions.

In light of the difficulties met by Nova Esperança, this approach to placemaking should take several theoretical and methodological points into account. Firstly, place is important even though a sense of community may be weak. This is not to say that community is less important than place. Rather, we mean that a community cannot be forced to exist, that the existence of place does not depend on it, and that place may induce community. Secondly, the variety of individual interactions with the milieu is constitutive of place and makes it possible to escape the "local trap". As interactions occur on a wide variety of scales, place cannot be reduced to a particular local territory nor to a simple set of networks. It includes both types of spatial relations. Thirdly, as reflexivity and self-organisation come out as fundamental elements of sustainable places, the political dimension of sustainability policies should be enhanced. Sustainable places are democratic places; they need various forms of public space in order to avoid individual initiatives and creativity to be curbed by social or environmental constraints. From a geopolitical viewpoint, place may be a means for resisting and thwarting external rules as well as to challenge exogenous power relations. Finally, as some environmental education projects have tried to do in Brazil, empowerment should be geared to the assessment of one's relationship to milieu, i.e., to the awareness of what constrains or facilitates one's place. Consequently, what place-based sustainability policies call for is more research on how to develop reflexive practices not only among inhabitants but also among planners. Unexpectedly, this may well give Turner's theory of the frontier some of the empirical justification 
that it never obtained: Could new environmental planning practices emerge from place-making experiments in the eco-frontier? 


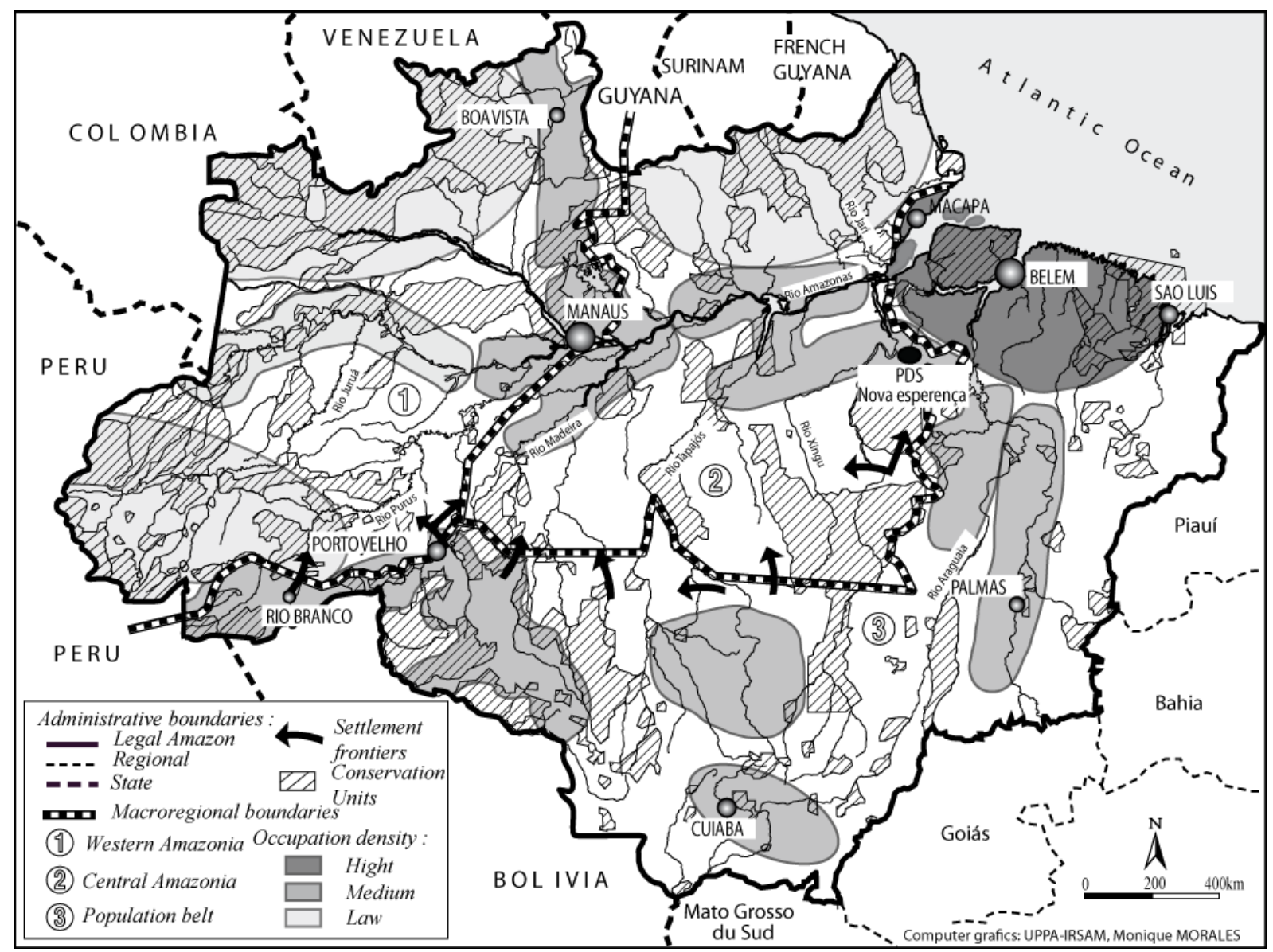

Fig. 1 - Zoning of the Amazon according to the Brazilian Sustainable Development Plan, and location of the PDS Nova Esperança 

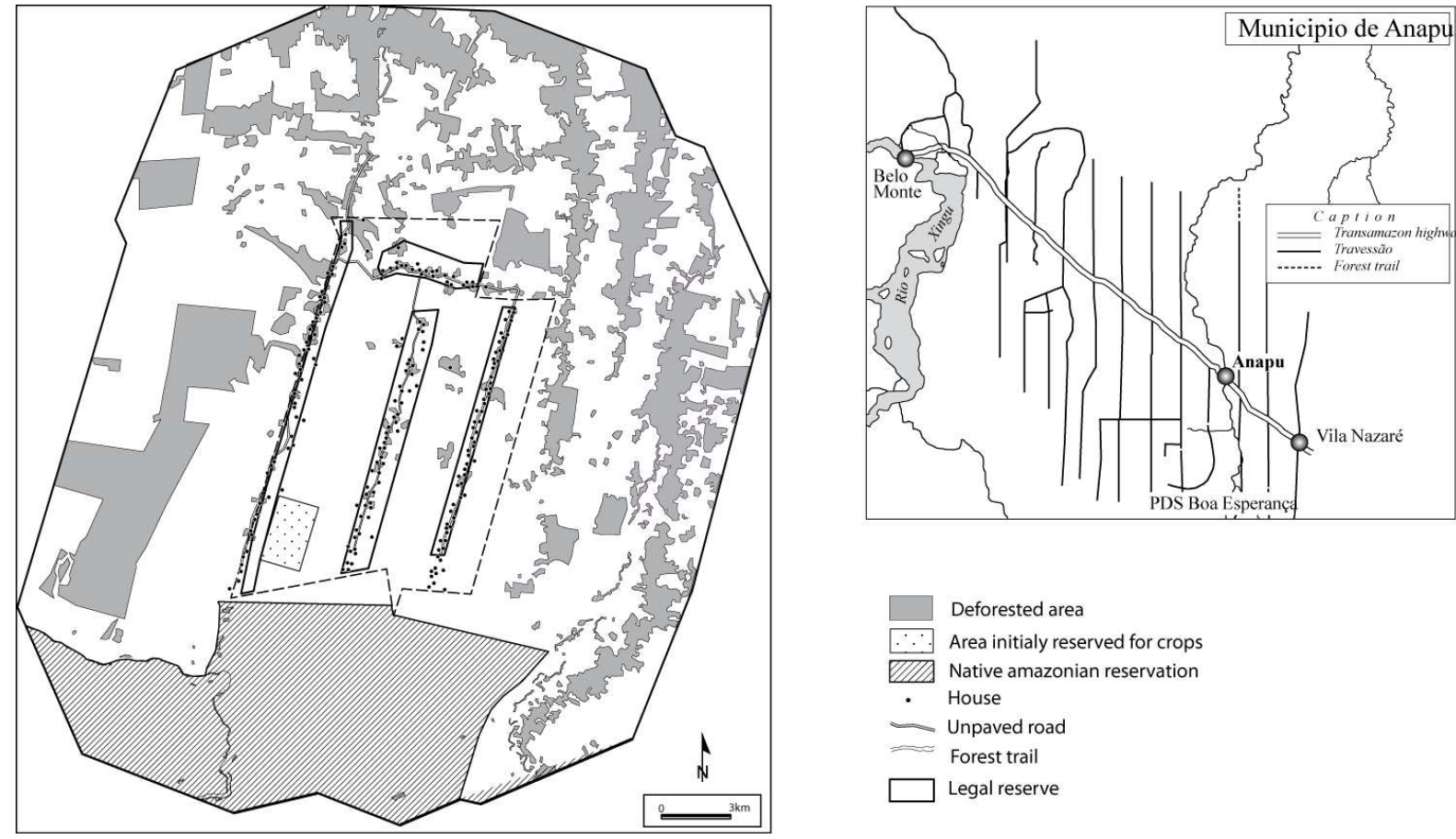

Fig 2 - The PDS Boa Esperança and the Anapu municipio

S. Hecht and A. Cockburn, The fate of the forest. Developpers, destroyers and defenders of the Amazon (New York: Harper Collins Publishers 1990).

ii S. Hecht, 'Soybeans, development and conservation on the Amazon frontier', Development and change 36/2 (2005) pp. 375-404.

iii P. Léna, 'La forêt amazonienne: un enjeu politique et social contemporain', Autrepart 9 (1999) pp. 97-120; F. Pinton and C. Aubertin, 'Populations traditionnelles: enquête de frontière', in X. Arnauld de Sartre and C. Albaladejo (eds), L'Amazonie brésilienne et le développement durable (Paris: L'Harmattan, 2006); B.S. Soares Filho, D. Nepstad, L. Curran, G. Coutinho Cerqueria, R.A. Garcia, C. Azevedo Ramos, E. Voll, A. McDonald, P. Lefebvre, P. Schlesinger, 'Modelling conservation in the Amazon basin', Nature 440/23 (2006) pp. 520-523.

iv S. Héritier, X. Arnauld de Sartre, L. Laslaz and S. Guyot, 'Fronts écologiques : dynamiques spatio-temporelles et dominations multi-scalaires - proposition d'une grille de lecture des processus de colonisation écologique. L'espace politique 3/2 (2009) http://espacepolitique.revues.org/index1453.html

${ }^{v}$ C.S. Simmons, R.T. Walker, E.Y. Arima, S.P. Aldrich, and M.M. Caldas, 'The Amazon Land War in the South of Pará', Annals of the Association of American Geographers 97/3 (2007) pp. 567 - 592; X. Arnauld de Sartre and R. Taravella, 'National sovereignty vs. sustainable development. Lessons from the narrative on the internationalization of the Brazilian Amazon', Political Geography 28/7 (2009) pp. 406-415.

${ }^{\mathrm{Vi}}$ O.G. Velho, Frentes de expansão e estrutura agrária (Rio de Janeiro: Zahar editores 1972); P. Léna, C. Geffray, R. Araújo, ed., L'oppression paternaliste au Brésil (Paris: Karthala Lusotopie 1996) ; C. Brannstrom, 'Producing possession: labour, law and land on a Brazilian agricultural frontier, 1920-1945', Political Geography 20/7 (2001) pp. 859-883. 
vii Léna (note 3); P.M. Fearnside, Land-Tenure Issues as Factors in Environmental Destruction in Brazilian Amazonia: The Case of Southern Pará', World Development 29/8 (2001) pp. 1361-1372.

viii C.S. Simmons, R. Walker, S. Perz, S. Aldrich, M. Caldas, R. Pereira, F. Leite, L.C. Fernandes, E. Arima, 'Doing it for Themselves: Direct Action Land Reform in the Brazilian Amazon', World Development 38/3 (2010) pp. 429-444.

ix F.M. Le Tourneau and M. Droulers (eds) L'Amazonie brésilienne et le développement durable (Paris: Belin 2011).

$x$ S. Guyot, 'Genesis of ecofrontiers: analogies, invention and representations', Geopolitics, this issue (2011).

${ }^{x}$ M. Power, 'Geopolitics and "development": an introduction', Geopolitics 15/3 (Special Issue: Geopolitics and development) (2010) pp. 433-440.

xii S. Dalby, 'Critical geopolitics: discourse, difference and dissent', Society and space 9 (1991) pp. 261-283; S. Dalby, 'Imperialism, domination, culture: the continued relevance of critical geopolitics', Geopolitics 13/3 (2008) pp. 413-436; S. Dalby and G. Ó. Tuathail, 'Editorial introduction: The critical geopolitics constellation: problematizing fusions of geographical knowledge and power', Political Geography 15/6-7 (1996) pp. 451-456.

xiii D. Gibbs and R. Krueger, 'Exploring local capacities for sustainable development', Geoforum 36/4 (2005) pp. 407-409.

xiv C. Aubertin, 'Les produits forestiers non ligneux, outil de la rhétorique du développement durable', Natures Sciences Sociétés 10/2 (2002), pp. 39-46.

${ }^{\mathrm{xv}}$ L. Sharp, 'Local policy for the global environment: In search of a new perspective', Environmental Politics 8/4 (1999), pp. 137-159

xvi J. Houghton, "Place and the implications of "the local" for sustainability: an investigation of the Ugu District Municipality in South Africa', Geoforum 36/4 (2005), p. 427.

${ }^{x v i i}$ C. Brown and M. Purcell, 'There's nothing inherent about scale: political ecology, the local trap and the politics of development in the Brasilian Amazon', Geoforum 36/7 (2005) pp. 607-624.

${ }^{x v i i i}$ B.H. King, 'Conservation and community in the new South Africa: A case study of the Mahushe Shongwe Game Reserve', Geoforum 38/1 (2007), pp. 207-219.

xix S. Brint, 2001. 'Gemeinschaft Revisited: A Critique and Reconstruction of the Community Concept', Sociological Theory 19/1 (2011) p. 9.

${ }^{\mathrm{xx}}$ Ibid.

${ }^{\mathrm{xxi}}$ F. Ellis, Rural livelihood and diversity in developing countries (Oxford: Oxford University Press 2000).

${ }^{x x i i}$ X. Arnauld de Sartre, Front pionnier d'Amazonie: Les dynamiques paysannes au Brésil (Paris: CNRS éditions, 2006).

${ }^{x x i i i}$ E. Stratford, D. Armstrong and M. Jaskolsk, 'Relational Spaces and the Geopolitics of Community Participation in Two Tasmanian Local Governments: A Case for Agonistic Pluralism?', Transactions of the Institute of British Geographers, 28/4 (2003) pp. 461-472; J. Olsson, 'Sustainable development from below: institutionalising a global idea-complex', Local Environment 14/2 (2009), pp. 127-138.

xxiv S.A. Marston, 'The social construction of scale', Progress in Human Geography 24/2 (2000), pp. 219-242; S.A. Marston, J.P. Jones and K. Woodward, 'Human geography without scale', Transactions of the Institute of British Geographers 30/4 (2005), pp. 416-432. 
$x_{x v}$ T. Forberg, 'The ground without foundations? Territory as a social construct', Geopolitics 8/2 (2003), p. 7.

${ }^{x x v i}$ Brown and Purcell (note 17).

xxvii J. Agnew, 'The territorial trap: The geographical assumptions of international relations theory', Review of International Political Economy 1/1 (1994) pp. 53-80.

xxviii N. Brenner, 'The limits to scale? Methodological reflections on scalar structuration', Progress in Human Geography 25/4 (2001), pp. 591-614.

${ }^{x x i x}$ H. Bulkeley, 'Reconfiguring environmental governance: Towards a politics of scales and networks', Political Geography 24/8 (2005), pp. 875-902.

${ }^{\mathrm{xxx}}$ Houghton (note 16), p. 419.

xxxi J. Agnew, Place and politics (Boston: Allen and Unwin 1987); V. Berdoulay, Des mots et des lieux. La dynamique du discours géographique (Paris : Editions du CNRS 1988); J. Agnew and J. Duncan (eds.) The power of place: Integrating geographical and sociological imaginations (Boston and London: Unwn Hyman, 1989); R.J. Johnston, A question of place. Exploring the practice of geography (Oxford: Blacwell 1991); E.S. Casey, The fate of place (Berkeley and Los Angeles: University of California Press 1997); K. Cox (ed) Spaces of globalization: Reasserting the power of the local (New York: Guilford 1997); T. Cresswell (2004). Place: A short introduction (Oxford: Blackwell 2004); R. Haesbaert, $O$ mito da desterritoriaização (Rio de Janeiro: Bertrand Brazil 2004); D. Massey, For space. (London: Sage 2005); J.N. Entrikin, ed., Region: Critical essays in human geography. Farnham: Ashgate 2008).

${ }_{\text {xxxii }}$ S. Pile and M. Keith (eds), Geographies of resistance (London: Routledge 1997); S. Pile and N. Thrift (eds), Mapping the subject: Geographies of cultural transformation (London Routledge 1995)

xxxii C.S. Simmons, 'Territorializing land conflict: Space, place, and contentious politics in the Brazilian Amazon', Geojournal 64 (2005), pp. 307-317; C.S. Simmons, M. Caldas, S. Aldrich, R. Walker, and S. Perz, 'Spatial processes in scalar context: development and security in the Brazilian Amazon' Journal of Latin American geography 6/1 (2007), pp. 125-150; C.S. Simmons, R. Walker, S. Perz, S. Aldrich, M. Caldas, R. Pereira, F. Leite, L.C. Fernandes and E. Arima, 'Doing it for Themselves: Direct Action Land Reform in the Brazilian Amazon', World Development 38/3 (2010), pp. 429-444 ; W. Wolford, 'This land is ours now: Spatial imaginaries and the struggle for land in Brazil', Annals of the Association of American Geographers 94/2 (2005) pp. 409-424; T. Ludewigs, A. De Oliveira d'Antona, E.S. Brondizio, S. Hetrick, 'Agrarian structure and land-cover change along the lifespan of three colonization areas in the Brazilian Amazon', World Development 37/8 (2009), pp. $1348-1359$.

xxxiv H. Lefebvre, The production of space (Trans. D. Nicholson-Smith, Malden: Blackwell 1991).

${ }_{\mathrm{xxxv}}$ A. Frémont, La région, espace vécu (Paris: Presses Universitaires de France 1976); Y.F. Tuan, Space and place. The perspective of experience (Minneapolis: University of Minnesota Press 1977); E.S. Casey, Getting back into place (Bloomington: Indiana U.P. 1993); R.D. Sack, Homo geographicus (Baltimore: Johns Hopkins University Press 1997); A. Berque, Ecoumène. Introduction à l'étude des milieux humains (Paris: Belin 2000).

${ }^{x x x v i}$ M. Keith and S. Pile (eds), Place and the politics of identity (London: Routledge 1993); Pile and Thrift (note 32).

xxxvii J.N. Entrikin, The betweenness of place: towards a geography of modernity (Baltimore: Johns Hopkins University Press 1991). 
xxxviii A. Pred, 'Place as historically contingent process: Structuration and the timegeography of becoming places', Annals of the Association of American Geographers 74/2 (1984), pp. 279-297; A. Escobar (2001), 'Culture sits in places: Reflections on globalism and subaltern strategies of localization', Political Geography 20/2 (2001), pp. 139-174; V. Berdoulay, 'Planifier avec le milieu: les liens complexes de l'analyse et de 1'action', BELGEO 5/3 (2004), pp. 231-241; J.N. Entrikin and V. Berdoulay, 'The Pyrenees as place: Lefebvre as guide', Progress in Human Geography 29/2 (2005), pp. 129-147.

${ }^{x x x i x}$ V. Berdoulay and J.N. Entrikin, 'Lieu et sujet. Perspectives théoriques', L'espace géographique 2 (1998), pp. 111-121; V. Berdoulay, D. Laplace-Treyture, X. Arnauld de Sartre, 'La question du sujet et la géographie', Cahiers de géographie du Québec 54/153 (2010), pp. 397-418.

${ }^{\mathrm{xl}}$ P. Freire, Pedagogia do oprimido (Rio de Janeiro: Paz e Terre 1972).

${ }^{x l i}$ M. Sorrentino, Ambiantalismo e participação na contemporaneidade (São Paulo: EDUC-FAPESP 2001).

xlii V. Berdoulay and J.N. Entrikin, 'Singularité des lieux et prospective', Espaces et sociétés 74-75 (1994), pp. 189-202. Berdoulay and Entrikin (note 39). O. Soubeyran, 'Entre distance et bonne distance: Territoire, sens et action', in C. Maumi (ed.), Pour une poétique du détour. Rencontre autour d'André Corboz (Paris: Editons de la Villette).

xliii W. Laurance, M. Cochrane, S. Gergen, P. Fearnside, P. Delamonica, C. Barber, S. d'Angelo and T. Fernandes, 'The future of the Brasilian Amazon', Science, 291/5503 (2001) pp. 438-444.

xliv S. Abakerli, 'A critique of development and conservation policies in environmentally sensitive regions in Brazil', Geoforum 32/4 (2001) pp. 551-565.

xlv S.P. Eudaily and S. Smith, 'Sovereign Geopolitics? - Uncovering the Sovereignty Paradox’ Geopolitics 13/2 (2008), pp. 309-334.

xlvi Simmons, Caldas et al. (note 33 ).

${ }^{x l v i i}$ M. Röper, 'On the way to a better State? The role of NGOs in the planning and implementation of protected areas in Brazil', Geojournal 52 (2000), pp. 61-69.

${ }^{\text {xlviil }}$ X. Arnauld de Sartre and V. Berdoulay, Politiques territoriales et développement durable. Leçons d'Amazonie (Paris: Quae 2011).

${ }^{x l i x}$ E.g. C.W. Porto Gonçalvez, Os (des)caminhos do meio ambiente (São Paulo:

Contexto 1989).

${ }^{1}$ C.A.F. Monteiro, A questão ambiental no Brasil: 1960-1980 (São Paulo: IGEO/USP 1981).

${ }^{\text {li }}$ Sorrentino (note 41).

lii R. Toledo Neder, Crise socioambiental. Estado e sociedade civil no Brasil (19821998) (São Paulo : Annablume Fadesp 2002); J. Eli da Veiga, A emergência socioambiental (São Paulo: Editora Senac 2007).

liii X. Arnauld de Sartre, 'La colonisation de l'Amazonie face au développement durable: L'exemple du barrage de Belo Monte', Cahiers des Amériques latines 44 (2004), pp. 159-174.

liv Simmons, Walker et al. (note 33).

${ }^{1 v}$ DURAMAZ, supported by the Agence nationale de la recherche, France

lvi R.d.S. Lopes, O letramento selvagem. Um estudo sócio-antropológico da apropriação da escrita por trabalhadores rurais assentados em área de reforma agrária na região da Transamazônica (Belém: Doctorado em ciencias sociais. Universidade federal do Pará 2009). 
${ }^{\text {lvii }}$ We have studied other populations from the assentamentos of the agrarian reform in the same region with the same protocol of survey. We have done some tests in order to see if the population of the PDS Boa Esperança was different from these other populations (tests comparing two independent samples) with the same indicators as in table 1 , and we did not find any differences.

lviii Simmons (note 33).

lix Arnauld de Sartre (note 22).

${ }^{\mathrm{lx}}$ Brint (note 19). 